\title{
A STUDY ON THE PALPEBRAL AND CONJUNCTIVAL HEMORRHAGE PRODUCED BY THE IRRITATION OF THE BUCAL MUCOSA OF THE RAT.
}

$\mathrm{By}$

\author{
E. SAITO
}

\section{From the Department of Oto-Rhino-Laryngology, School of Medicine Keio University (Director: Prof. T. Nishihata)}

It is not an infrequent experience to see a subcutaneous hemorrhage in the eye-lid or conjunctiva localized not always ipsilaterally but sometimes contralaterally after an Oto-Rhino-Laryngological operation, especially after a sinus operation.

In order to eludidate the cause of the hemorrhage, the author performed the following experimental study on the rat: croton oil was injected into the tissue of the wall of the paranasal sinus or into the buccal mucosa through the lip. Ipsi- or contralateraly located palpebral hemorrhage was obeerved to occur following the injection.

Histological study of the palpebral tissue revealed that the lesion was mainly due to the vascular disturbance with edema, vaso-dilatation, stagnation of blood cells and hemorrhage, as well as localized necrosis in severly damaged areas.

Lesions were also found in the lungs, liver, kidneys and other organs. Suzuki, Iida and Fukazawa described similar lesions due to vascular disturbance in those organs of the pig produced as a manifestation of the Reilly's phenomenon.

In the author's experiment, intensity of the palpebral hemorrhage and of the lesions in those organs pararelled with each other.

These facts has induced the author to interprete the hemorrgagic lesion in the eye-lid as a manifestation of the Reilly's phenomenon.

\section{ラツテの煩部過剩刺戟により生ずる眼瞼部 出血に関する研究}

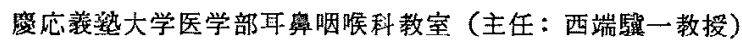

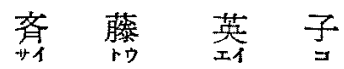

目次

1.はしがき

2. 実験方法

3. 实臨成繦

i）クロトン油注射後の眼臉部の変化

ii) 眼臉部の病理組織学的所見

iii）クロトン油注射後の眼瞼部変化の発現時日にっ w.

iv）クロトン油注射後のラッテの死亡について v) 内䁾臓器の病理組織学的所見

4. 総括及び考按

5. むす び

\section{1.はしがき}

耳鼻咽唉科领域の手術後儿，手術野から離れた部位に 皮下出血が認められることがある。もつとも多いのは副 鼻腔炎の手術後に眼瞼皮下，あるいは結膜下に認められ る出血で，高度のときは顔面広範围に亘つて溢血として 認められる.この現象は耳鼻咽唉科医が観察していた等 
であるが，従来は，その部位を圧迫したつめであるらと 考之，特汇梁く追波されていなかつた．しかし，手術持 飞注意して皮房を压迫しない上うにしても，か」る現象 㹥生ずる. 又腿臉皮下出血, 結膜下出血は手衍側のみな らず，反対側ども起ることがある。ごあ文対僛他も起る ことから考えても手術時に直接その部位を任迫したり， あるいは手術操作忨よる直接的の血管破綻とは考兄難 い. 鈴木 (安) ら 10) はか子る患者の臨床例を 報告し, このような患者の植物神経機能を調へ，はなはたしい植 物神経のアンバランスが存在することを認めている.

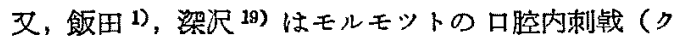
ロトン油使用)に上るショックの発現を認め，之の際の 遠隔諸臓器に浮腫, 出血などの血管采障碍が起ることを 観察した。これは主として植物神経を軸とする血管運動 神経の過剩反応によるものであるといつている.

私恃前記の 非術後化 起る皮下出血は，やはり手術時 （あるいは手術創）に沶ける刺㦸が植物神経を介して過 剩反沁を起し，出血などの血管系障碍を起すためではな

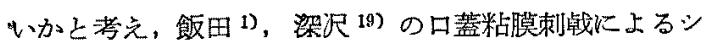
ヨック実験に用いた方法に準じてクロトン油を使用し， ラッテの鼻腔側壁粘膜下より煩部に，又口腔内より煩部 皮下組織内注射し，過㮃刺践を与克た。

その結果として眼臉部の出血を伴う病変の起るのを観 察した。更に眼臉部及び内臓蔵器の病理組織学的検索を 行い,この変化は所謂 Reilly 氏莧象の所見に類似して 中ることを認めた。

\section{2. 実験方法}

実験には体重 150〜200gr のラッテを使用し，性別は とくに考慮せず，成熟した漣康なるのを選んだ。

鼻腔及び口腔を通して，规部への過剩刺戱の目的炕は

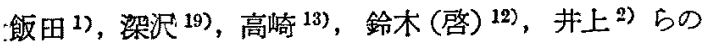
一連の実験結果より推察してクロトン油の注入が適当で あると考えてこれを使用した。

まずエーテルによるなるべく浅い全身麻酔を行つた 後に皮内注射用の $1 \mathrm{cc}$ 注射器飞, 内径 $1 / 2 \mathrm{~mm}$ の針を 使用して鼻孔を通して奥腔側壁粘膜下にクロトン油原液 ゆ.1 cc または 0.2cc を注射した。

同样に口腔上り煩部皮下組織にクロトン泊原液 $0.1 \mathrm{cc}$ または $0.2 \mathrm{cc}$ 確実注射した。この際, 毎回注射針が 血管内に入らないことを注射筒を引いて確認し，から固 有番腔内やその他の部位に漏机ることのないように十分 注意して注入した。少しでもクロトン油の瀮れたすのは 実験成積より除外した。
浅いエーテル唒下のラッテは注射後 1 2 分で党醒 し，その後は平常通り運動するようになる. 注射後は特 別な 伅置を施すことなく放置し, 眼周囲の出血, 充露 血, 潰眗形成などの所見を 10 日間観察すると共に，死

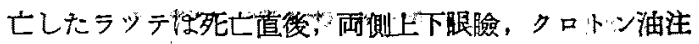
入部位及び内蔵諸藏器(肺, 心, 肝, 惄, 副腎, 腸, 脾) の病理組織学的検查を施行した。

又一部怡生存中にェーテル麻酔下に生体解剖を行い, 同様の検查を行つた。

対象として背部皮下にクロトン弾原液 $0.1 \mathrm{cc}$ あるいは $0,2 c c$ を注射し, 其腔粘膜下注射群, 口唇部皮下注射群 々同樣の観察および検查省施行した。

\section{3. 実験成績}

上記実験方法により 3 群に分けて観察した。

第 【群： 片側鼾腔側壁粘膜下組織内注入したもの (以下, 究粘膜下注射群之記載)

$\left.\begin{array}{l}\text { A 群：クロトン油 } 0.1 \mathrm{cc} \text { 注入したもの } 13 \text { 例 } \\ \text { B 群: クロトン渵 } 0.2 \mathrm{cc} \text { 注入したもの } 6 \text { 例 }\end{array}\right\}$ 計19例 第】群：口腔上り片僛の頝部皮下組繶内に注入した むの（以下，口唇部皮下注射群と記载）

$\mathrm{A}$ 群：クロトン活 $0.1 \mathrm{cc}$ 注入したもの13 例 B 群：クロトン油 $0.2 \mathrm{cc}$ 注入したもの 4 例 計17例 第更群：背部皮下組織内に注入したるの

$\left.\begin{array}{l}\mathrm{A} \text { 群：クロトン油 } 0.1 \mathrm{cc} \text { 注入したもの3 例 } \\ \mathrm{B} \text { 群: クロトン油 } 0.2 \mathrm{cc} \text { 注入したもの3 例 }\end{array}\right\}$ 計 6 例

i)クロトン油注射後の眼臉部の肉眼的变化

変化のはなはだしいるのは注射翌日にして両眼臉，特 に内㫮部近く，その变化恃著明で，表皮は浅い謴富を 形成乙，黑裀色の污㶓な血性出物加附着する。眼球結 膜恃軽度に混罚寸るすのと变化のないるのとある（図1 参喃).

变化の軽度のむのは脂瞼部に軽い:安下出血之思われる 所見が認奴れるのみで，他法別な变化を認めない (図2).

及，皮下出血に軽度の潰牊を伴うものがある(図3）。 又全く変化の起きないのあある。

以上の上うにその変化の甚しいものを(H)，変化の 軽いものを(十), 変化のないるのを(ー)とすると、そ の発現する頻度は第 1 表の如くである。

すなわち率腔粘膜下注射群では，強度变化は，注射同 側 19 例中 7 例 $(35.8 \%)$, 区対側 19 例中 ! 例 $(5.3 \%)$, 軽度变化生注射同例 19 例中 8 例 $(42.1 \%)$, 反対側 19 例 中 8 例 $(42.1 \%)$ ，変化のないものは注射同側 19 例中 4 
例 $(21.1 \%)$ ，反对側は 19 例中 10 例 (52.6\%) である。

第 1 表 クロトソ油注射後の眼瞼部出血性变化 の発現菜

\begin{tabular}{|c|c|c|c|c|c|c|c|c|}
\hline \multirow{2}{*}{ 注射 } & \multirow{2}{*}{$\begin{array}{c}\eta ロ 卜 \text { 油 } \\
\text { の量. }\end{array}$} & \multirow{2}{*}{$\begin{array}{l}\text { 例 } \\
\text { 数 }\end{array}$} & \multicolumn{3}{|c|}{ 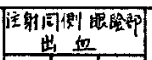 } & \multicolumn{3}{|c|}{ 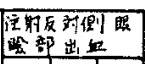 } \\
\hline & & & $H$ & + & -1 & $\mathrm{H}$ & + & $=$ \\
\hline \multirow{2}{*}{ 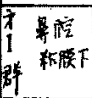 } & 㫊上油 & 13 & $4^{\text {fot }}$ & $6^{\text {PN }}$ & $3^{\text {की }}$ & $0^{91}$ & $s^{8 S^{21}}$ & $8^{9}$ \\
\hline & $0,2<$. & $6^{\text {83n }}$ & 3 & 2 & 1 & 1 & 3 & 2 \\
\hline \multirow{2}{*}{ 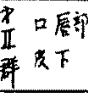 } & $\begin{array}{l}701=\text { 油 } \\
0.164\end{array}$ & $13^{4011}$ & 2 & 8 & 3 & 0 & 4 & 9 \\
\hline & & $4^{13}$ & 3 & 1 & 0 & 1 & 2 & 1 \\
\hline \multirow{2}{*}{ 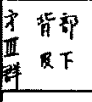 } & $\begin{array}{c}701=\text { 油 } \\
0.1 c c\end{array}$ & $3^{191}$ & 0 & 0 & 3 & 0 & 0 & 3 \\
\hline & $0.2 \mathrm{kc}$ & $3^{19}$ & 0 & 0 & 3 & 0 & 0 & 3 \\
\hline & & $42^{D \prime}$ & 12 & 17 & 13 & 2 & 14 & 26 \\
\hline
\end{tabular}

口唇部皮下注射群では，強度変化は 注射同側 17 例中 5 例 $(29.4 \%)$, 反対侧 1 例 $(5.9 \%)$, 軽度变化佉同側 17 例中9 例 $(52.9 \%)$, 反対側性 6 例 $(35.3 \%)$, 変化のな い60は注射同側 17 例中 3 例 $(17.6 \%)$ ， 反対側怯 10 例 (58.8\%) であつた.

背部、安下注射群 6 例は全例，雨側业眼瞼部の変化法皆 製であつた。

以上を総括するとクロトン油 0.1 〜 0.20c を鼻腔粘膜 下注射，もしくは口唇部皮下に注射すると注射同側では 刋 $80 \%$ に眼臉の出血情変化が発現し, 䄪 $20 \%$ は変化が 現われなかつた。

注射反対側では約 $50 \%$ に眼臉の出血性変化が発現し， 約 $50 \%$ は発現しない。

背部注射群は全例発見しなからた。

ii) 眼瞼部の病理組織学的所見

眼瞼部の变化がどのような所見であるが病理組織学的 に調べた。

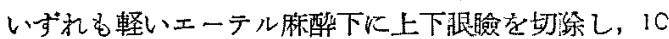
\%ホルマリン固定後，型の如く処理し，へマトキシリン エオジン染色を行い観祭した。

肉腿的にも比棪的強い出血性変化老認めた例では䐎臉 皮癄には血性渗出物が邖着し，浅在性の表皮の欠損を認 めることができる(図 4 )。

血管は一般に血球で光盈され，特汇その変化は表泣に 近い:宽下組織に著しく，時ては，出血をる認ふる(図 5)。

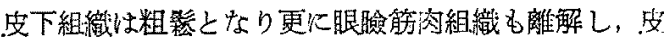

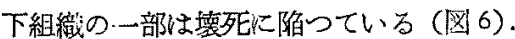

この猿死組織を中心に好中白血球の浸潤を著しく認め ることができる。
非常に軽度な肉眼的出血性変化の例に招いてむ同檥に

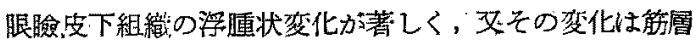

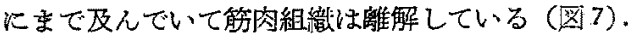

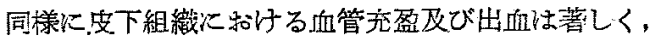

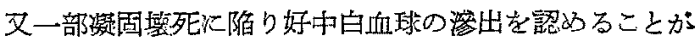
できた（図8）。

iii）クロトン油注射徯つ眼臉部变化の発現時日に 须

クロトン油注射後, 腿險部变化の発現恪 5 日以内にす へて甡現し，6日目になつて発現しないるのは，并れ以 上観察しても発現することはなからた。

注射同側で变化の発現した 29 例の中で 24 時間以内に 変化が現るれたるのは16例 (55.2\%)，注射反対側で变 化の発現した 16 例中 24 時間以内のもの6例 $(35.5 \%)$ であつた。

又 2 日目になると注射同側 29 例中 22 例 (75.9\%) が 発現し，反対側です16 例中 10 例 (62.5\%) が発現する. 3 日目になると, 注射同側29例中 26 例 $(89.7 \%)$, 反対 側 16 例中 14 例. (87.5\%) が発見与る。

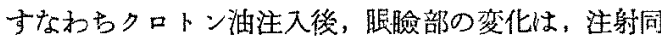
側では約半数が 24 時間以内に 発見し，注射後3日以内 に大部分が発現する。

㕛注射反刘側は同側より幾分掘れる傾向がるが 3 日 以内注射同側と同様大部分が発現する。

第 2 表クロトン油生射後の限臉部出血性变化 の発現時日

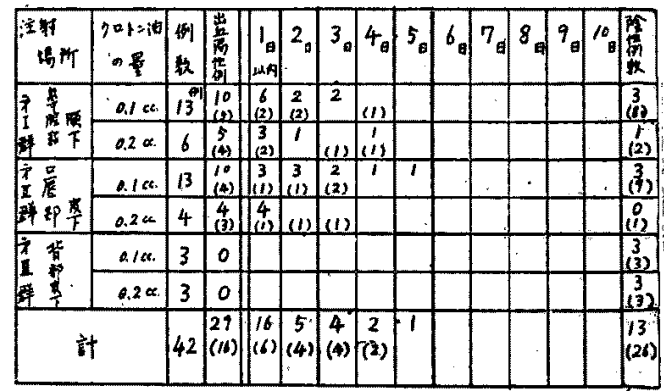

（）内は注射反刘㑡

iv）クロトン油注射後つラッテの死亡について

番腔側壁及び口唇部皮下にクロトン油を注射したラッ テは 10 日間の観察により 28 例中 20 例が死亡し 8 例が 生存したが，又背部皮下組䋨注注射した6 例は全例死亡 しなからた（生存中病理組䋨学的検案のため生体解剖を 行つた症例は除外す)。 
死亡例の死亡睹日は第3表に示与如く，注身後3日か ら7日の間にはとんどの例が死亡した。

第 3 表 クロトン油浅射後日数别の死亡例及び 生存例（生存中解剖したものは除く）

\begin{tabular}{|c|c|c|c|c|c|c|c|c|c|c|c|c|c|c|}
\hline $\begin{array}{l}\text { 注訝 } \\
\text { 号所 }\end{array}$ & 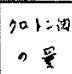 & 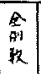 & 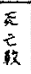 & D. & 2 & 3 & 4 & 5 & $\sigma_{n}$ & 7 & 8. & 9 & & 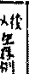 \\
\hline \multirow{2}{*}{ 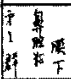 } & $0.1 \mathrm{ct}$ & $9^{\text {ब19 }}$ & 6 & & $1^{\text {in }}$ & $2^{\text {का }}$ & & $1^{17}$ & $i^{7}$ & $1^{6}$ & & & & $3^{\text {(1) }}$ \\
\hline & 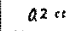 & 5 & 3 & & & 1 & & 1 & 1 & & & & & 2 \\
\hline \multirow{2}{*}{ tat } & a) & 9 & 7 & & & 1 & 2 & 2 & & 1 & & 1 & & 2 \\
\hline & $0.2 \mathrm{ca}$ & 3 & 3 & & & 1 & & 1 & & 1 & & & • & 0 \\
\hline \multirow{2}{*}{$\begin{array}{l}8 \text { 皆 } \\
\text { 繁 }\end{array}$} & $0.1 \mathrm{co}$ & 3 & 0 & & & & & & & & & & & 3 \\
\hline & $0.2 \mathrm{cc}$ & 3 & 0 & & & & & & & & & & & 3 \\
\hline \multicolumn{2}{|c|}{ 計 } & 32 & 19 & & 1 & 5 & 2 & 5 & 2 & 3 & & 1 & & 13 \\
\hline
\end{tabular}

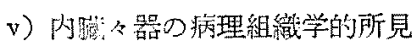

同時にクロトン油を注入したラッテの死亡例上生存列

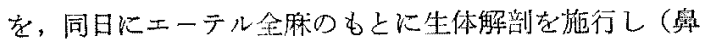

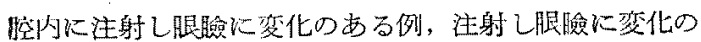
ない例及び背部皮下注射例)，その内蔵臓喜を肉眼的並 びに病理組織学的に比較検討した。

死亡例と生存例では明らかに胸䏝部の諸葴器に执いて 病変の程度が異つている。

死亡列では諸臟器の血管充盈, 出血等の循澴障碍が著

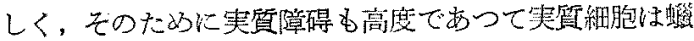

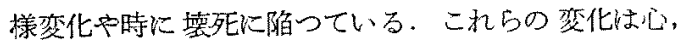
肺，肝，腎及び副腎等に扎いて、いずれも認めることが できる。なで肺においては，こ5した变化が著明て

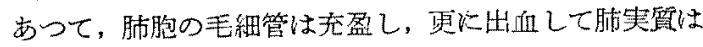
赤血球で充蓝されている。

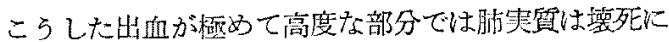
陷つていて，ての部分には好中白血球の出が著しく， いわゆる出血性の划梗塞梂の所見を呈している。

しかしながらこの際に，大血管には活とんど柽塞や内 膜炎等の变化を認わることがないので，以上のような卒

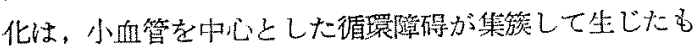
のと理解できる。

又それらの病变が鹏の各部分に散在性であることから 车大血管を中心とした循䝂障碍でないことが明らかであ 万.

一方生存例でも，眼臉部に出血性病变索起している例 では，肺胞の三細管充賈，肺胞内人の怪度の出血を認 め，眼瞼部に变化を起さなかつた例では烠胞壁の血管の 充盈による拡大を認める程度であつた。背部皮下注的例

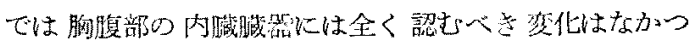
た。

\section{4. 捻括及び考按}

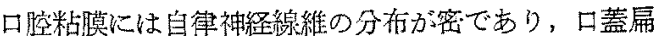
桃む网栐であつて，これらの部分の疾患がしばしば刺钱

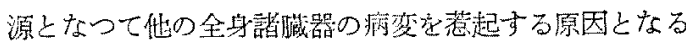

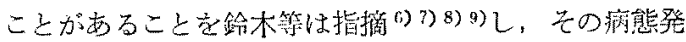
生に際して，自律神経とくに血管准動神経の週剩反応を

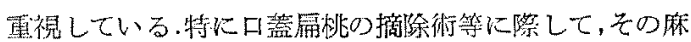

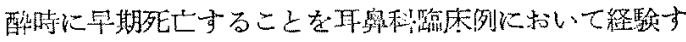

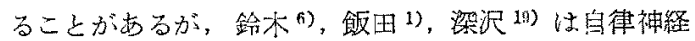
線維の分南の密なる口腔粘膜にごく徽量の（たと兄口腔

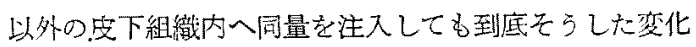
を起さぬ程度の)クロトン油を注入して激しいショック 様変化を起すことができることを，モルモツトを用いて 実験して率桃摘除術時偶発的毒故の理論的解明を試みて いる.

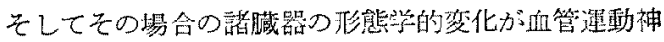
经の過剩反応による出血性变化であると或べている。

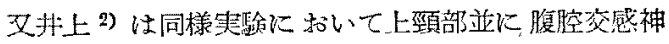

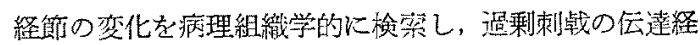
路の一として上頸交感神経節を介して，全身の自律神経 系におよら゙刺㦸之考えた。

山口ら 20021 《頸部及び腹腔の自律神経に遥剩な刺战 を加えて同様に諸咸器に，出血性变化を起し，それらが

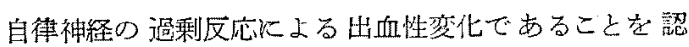
め,これらを自律神経の過剩反応に上る所謂 Reilly E 現象でするとしている。そして及 Chlorpromazineな と゚の自律神経遮盺成の投与が，これらの塄化の発現を抑

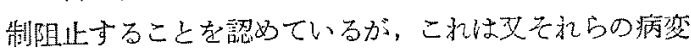
の発現が自律神経を軸として屡開したものであることを 証明するものと船することができる。

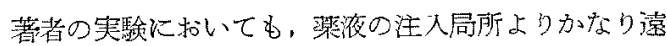

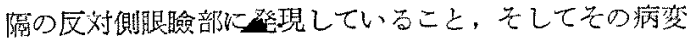
方病理組織学的に次て血管の浣盈上出血による局所の循

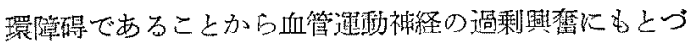
く局所毛維血管原の異常であると考光られる。

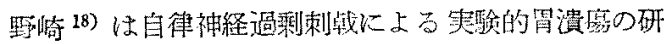

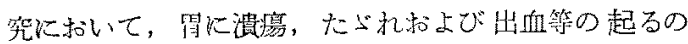
は粘脱下組織に和いて，血管理動神経の異常加ら起つた

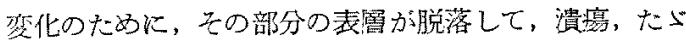
れなどの久損ができると述べており，自律神経の過剩刺

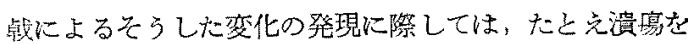


形成しなくても粘膜下組織に扣ける小血管の充盈や浮腫 性変化を重要視している。著者の実験において子病変の 著しい例では皮下組織の血管充盈，出血，浮腫户時壊 死を認め，その結果，限臉に出血性の啮寡が出現し，た と文漬瘍性変化を生じなくても皮下組織にかなりの循環 障碍を認めている. 従つて著者はクロトン油の注入か眼 瞼部皮下組㱍何小血管を中心とする血管運動神経の異常 をよびおこしたものと解している。

又同時にその際，鈴木らの）が口盖粘膜に刺战を加党，

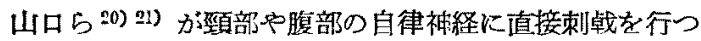
た際に認めたと全く同梯な激しい山血性変化を死亡群に 認めることができた．従つてこの鼻腔粘膜下組織へのク ロトン油注入がある場合には，かなり激しい自律神経の 過刮反応を萀起するるのであることを証明するるのと考 之られる，以上蒋液注入局所から，非連綕的にかなり， かけはなれた部分に病変が出現していることおよび出 血，たざれなどの病変が血管運動神経巽常により潰湯性 变化の出現に 類似すること, 更にこの楽液注入によつ て, 自律神経の過剩刺战に上る葴器変化が出現したこ と, 蔵器変化は死亡したものに强く, 又眼臉部の変化と 臓器变化が平行関係にあることなとかから，その藻液注入 が自律神経の刺战々なつて，眼睑部伅变化を起したもの と理解している.更に背部皮下に注入した場合には，全 く他の遠隔部位に変化をきたさなかつたことや，注入に 上る直接障碍でないことが組織变化で明かなことから， この具腔秥膜下組織へのクロトン油注射が充分, 自律神 経の刺战となり得るものであると考えられる。

しかしながら，この自律神経仩よる現象発現の神経儿 一トについては更に基礎的极研究を行う必要がある。局

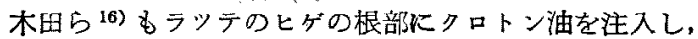
同側のみに腿臉出血が起るのを観察し，その発現に括け る自律神経反射の追求を行っている。

次に臨床例に和いて, 眼瞼の出血性变化の出現率と動 物実験の場合の出現率を比較してみると，かなりの祖異 があり，又，本実駼ではかなりの割合で死亡例が存在 し，諸臟器に相当の変化が出現している.これらのこと は動物実鈳では，かなり強い持続性の刺㦸であること， 文刺钱に対する生体の反応が動物と人間では異なること む考光られ，老の他，多くの条件が異り，実験之臨床之 の距りを感ぜさるを得ない。しかしながら動物実験に招 ける事実は，臨床における事実を説明するのに多くの示 唆を与点るものである.
扁桃摘除術時汇発生する偶発症も必らずしる多発する ものではないが，その病因を，一つの立場にたつて，解 明し，その过場から鈴木らは術前に自律神経遮断を行つ て，その偶発症の発生を㐨して効果を上げているが， 著者の実験で示した事实は，累腔，副鼻腔の手術後，

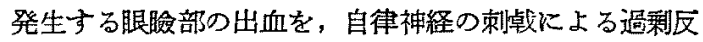
応の結果と考学ることができると共に，鼻腔への種々 なる刺战が一度若起したならば㯖慮すべき全身合併症の 出現の可能性を示装するものであり，郘床例において， 手術後などの僅かな局所変化の出現であつても，当然， 全身性の変化の出現の可能性を㕍慮して充分傎重な臨床 観察の要を意味するむのと解することができる.

鈴木ら ${ }^{10)}$ が報告した臨床観察において，出血性変化 を認めた症例の自律神経機能検査を行つて異常を発見し たことは，歌めて興味ある事実と考光る。

\section{5.むすひ}

1）ラッテの煩部に 身腔内および口腔内より，クロト ン油を注射して発現する眼臉出血を観察した。

2）眼臉出血は同側に 起る(約 80\%) だけでなく，反 対側にも起るすのがあつた（約 $50 \%$ ）.

3) 腿臉出血部の变化は浮腫, 血管充盈, 出血を主と する循環柔の変化が主として認められる.

4）死亡したるのに最も強い内䁍変化を認め，又，生 存例では, 眼瞼出血を起したものは, 起さないるのに比 較して内臓变化が強かつた。

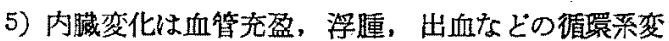
化を主としており，これに退行变性が加わつた像を呈し ていた.

6）背部皮下組織にクロトン油を注射したものは，眼 瞼部および内㓕諸葴器に変化を認めなかつた。

7）本実験の臨床的意義に就いて考察を加えてみた。

\section{文軽}

1) 飯田稔：耳鼻咽喉科，30 巻，3号，昭和 $33 . ， 2)$ 井上寿樹：日耳奥会報，63巻，4号，眧和 35.3$)$ 大

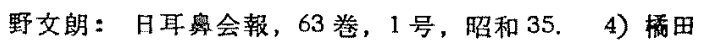

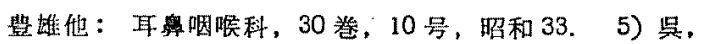
沖中：自律神経総諭, 炤和 31.6$)$ 6uzuki, Y. et al.: Keio J. of M. 7: 1958.7) 鈴木安恒他：日仏医学, 3 巻, 4 号, 昭和33. 8) 鉿木安恒他: 耳㽝咽喉科, 30 巻, 3 号, 昭和 33.9 ) 鈴木安恒：耳粤咽喉科, 30 巻, 8 号, 昭和 33.10$)$ 鈴木安恒他：日耳鼻会報，63 巻, 9 号, (演), 昭和 35, 11) Spransky, A.D.: A 
図 1

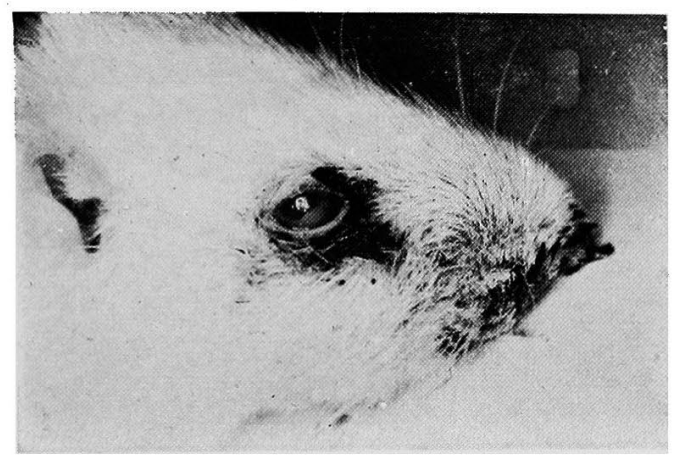

右側鼾腔倒壁内クロトン油 $0.1 \mathrm{cc}$ 注射例, 注射 後 3 日目の所見 (高度变化例)

图 3

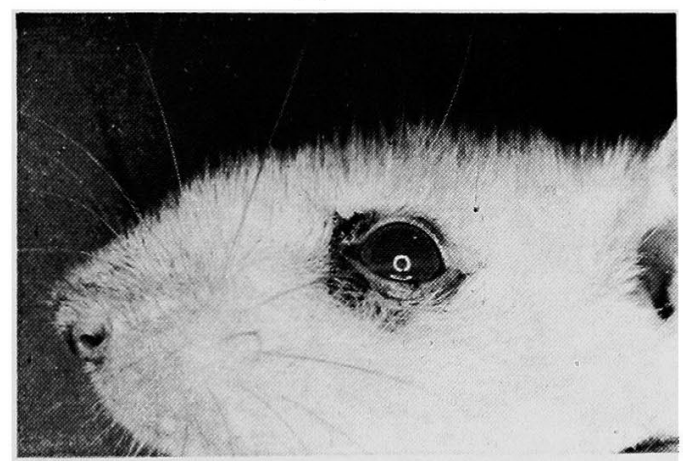

右側室腔側壁内クロトン油 $0.1 \mathrm{cc}$ 注: 射例注射後 2 日目の反対側眼睑所見 (㹩度出血例)
图 2

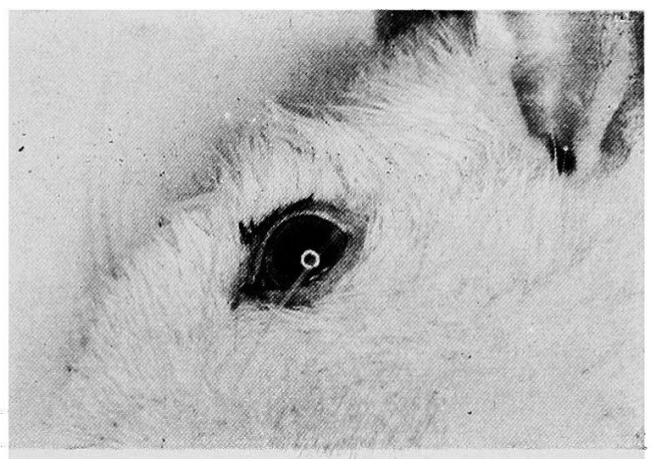

右側奥腔側壁内クロトン油 $0.1 \mathrm{cc}$ 注射例注射後

2 日目の反対側眼睑所見（軽度出血例）

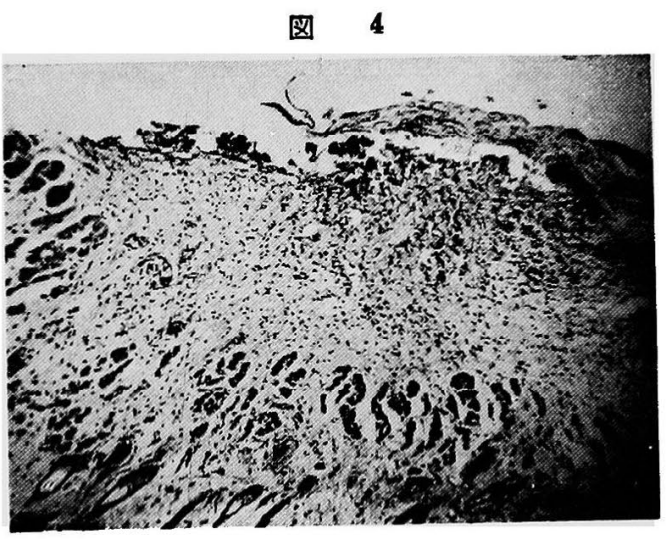

眼瞼：血性洷出物の附着した滇痬が認められる

\section{图 5}

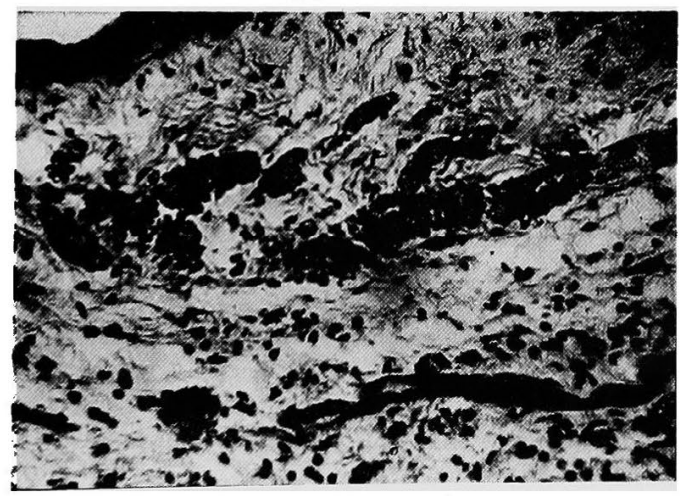

眼瞼：皮下組織の血管充盈と出血
図 6

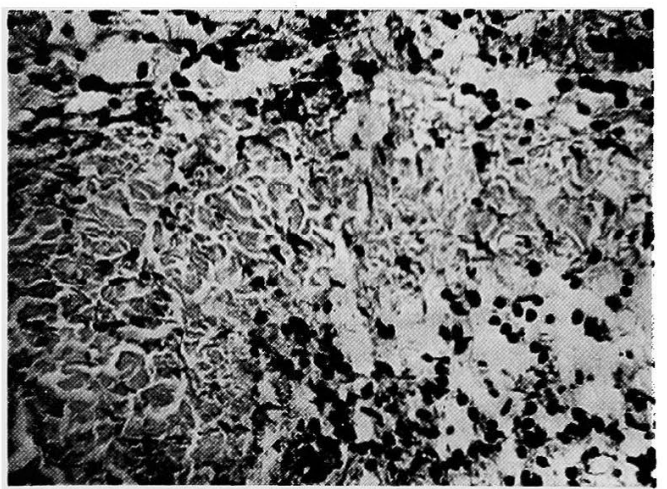

眼瞼：皮下組織の境死と好中白血球の渗出 


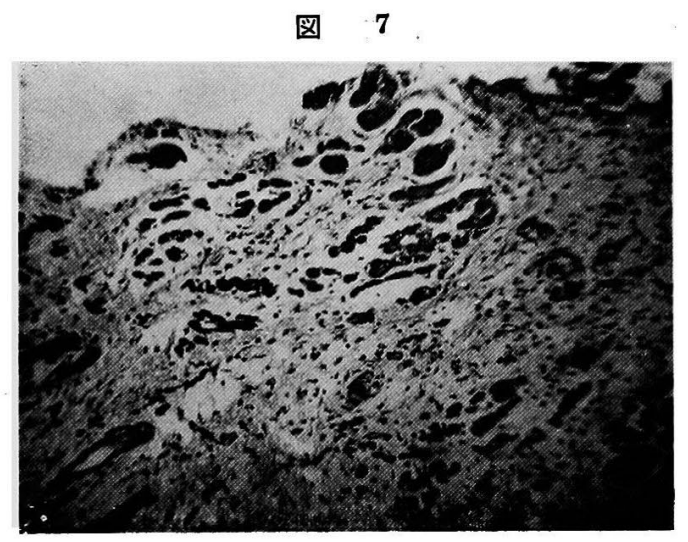

眼脸：皮下組織の浮喠と筋層の離解

\section{図 9}

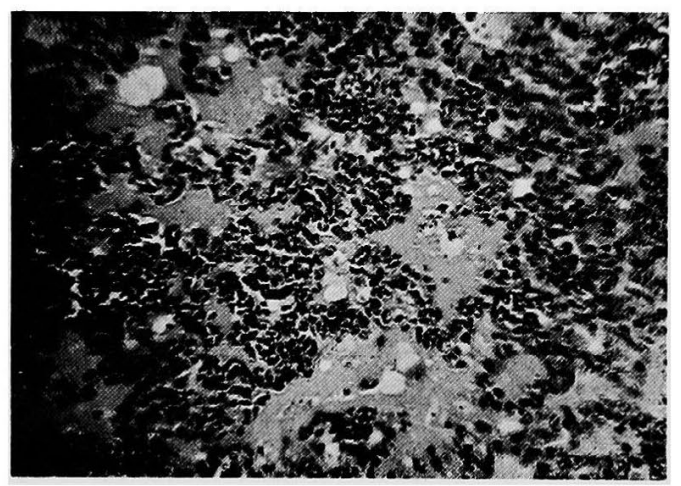

僦：血管充盈, 出血と肺胞内一の洛出（眼憸 出血性变化高度死亡例）

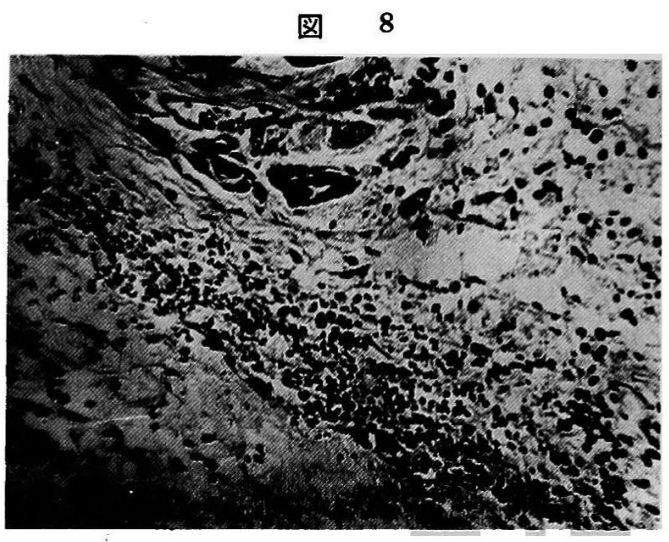

腿臉: 皮下組織の浮腫, 血管充盈, 出血々 白血球渗潤

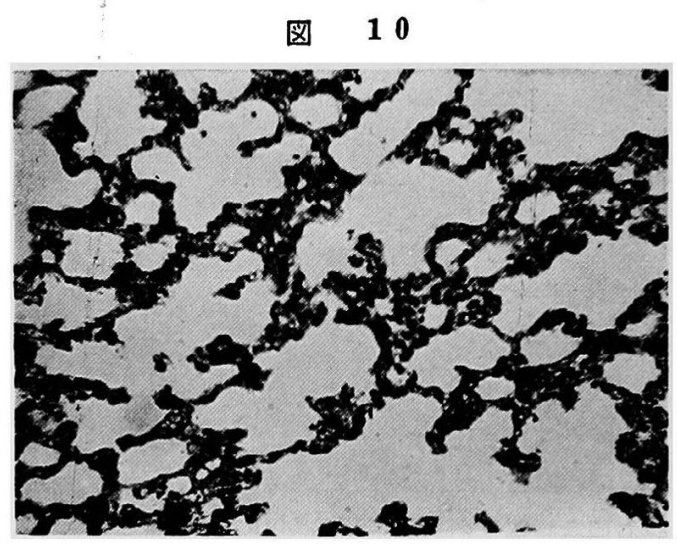

趽：軽度の血管抬張（眼瞼出血軽度生存例） 
basis for the theory of medicine 1947.

司：日耳番会報, 63 巻, 5 号, 昭和 35 .

12）鈴木啓 日耳奥会報, 63 巻, 5 号, 昭和 35 . 耳奥臨床, 52 巻, 7 号, 昭和 34 .

13）高崎晃: 14）竹内治一: 15）土屋雅春他: 日本内分泌学会雑誌，32 巻，10 号，昭和 31.16$)$ 戸 木田菊次他：口腔外科学会雑誌, 5 巻, 2 号, 昭和 34 .

17）氷瀬邦彦：日耳鼻会報， 61 巻，9号, 昭和 33 .

18）野崎英夫：日本外科学会雑誌，(揭載予定). 深沢久夫：耳鼻咽唉科； 30 巻, 3 号, 昭和 33.

山口与市：日本医事新報, 1665 号, 昭和 31.21$)$ 山 口与市：㿑応医学, 33 巻, 5 号, 昭和 31.22$)$ Reilly J.: Comp. Rend Soc. Biol, Tom. 148 (2) : 1954.
稿を終るに䧗み，恩師西端䜿一教授の御留篤 なる御指導と御校閲を深謝すると共に終始御指導, 御鞭撻を睗つた鈴木安恒助教授に厚く感謝 致します 又白石幸治郎博士，土屋雅春博士， 宮部耐医学士，杉山繁医学士の御指導, 御協力 と, 実験の場を与えられ, 且つ種々御援助を賜 つた日発病院の諸氏に感謝致します

本諭文の要旨は昭和 35 年 2 月, 関東地方会 第 367 回例会においてロ述した。

（原稿到着 $=$ 昭和 35.8 .29 日一急載）

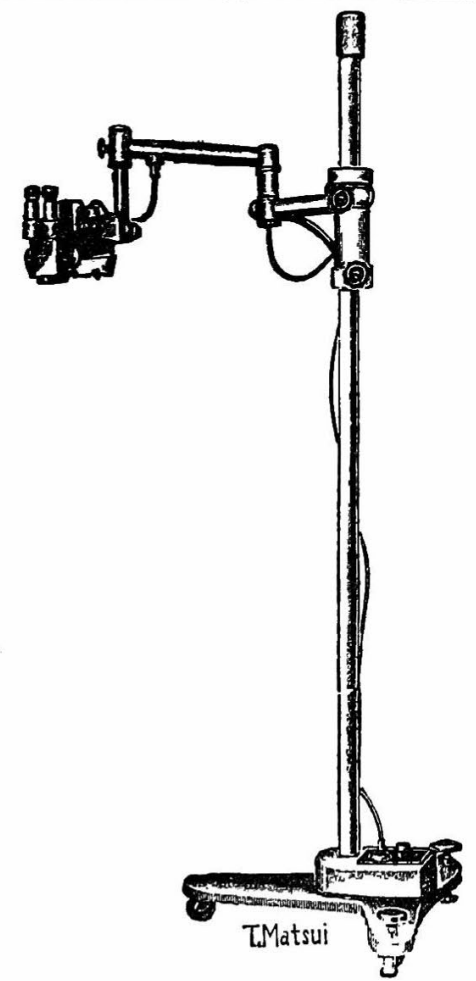

\section{T.M 式手術用双眼顕微鏡}

(倍率) $\times 6 \times 10 \times 16$

（特長）堅牢無比作動 円 滑

操作簡易 焦点深度大

価格低廉

（御希望に依り図解説明書を打送り致しまず）

耳鼻咽喉科気管食道科医療器械

\section{真隋}

東京都文京区本郷湯島二丁目四番地

電 話 小石川 (921) 0575 番 振替口座東京 77409 番 京都市東山区東大路松原下ル小島町一四二 電 話 祗 園（6）5521番 